\title{
Migracje XXI wieku jako wyzwanie dla bezpieczeństwa Polski oraz Unii Europejskiej
}

https://doi.org/10.19195/2083-7763.10.7

Abstrakt

Artykuł zawiera rozważania na temat migracji i jej wpływu na bezpieczeństwo Polski oraz innych państw Unii Europejskiej. Autorka wskazuje zarówno pozytywne, jak i negatywne skutki emigracji z Polski oraz imigracji, będącej wynikiem arabskiej wiosny ludów, do krajów europejskich i wpływ na poszczególne dziedziny bezpieczeństwa.

Słowa kluczowe: bezpieczeństwo, migracja, przyczyny i skutki

\section{Wprowadzenie}

Migracje są cechą charakteryzującą gatunek ludzki. Od zawsze człowiek przemieszczał się z miejsca na miejsce, stąd też pochodzenie tego słowa od łacińskiego migratio oznacza wędrówkę. Przed pojawieniem się państw narodowych migracje regulowały zazwyczaj wojny, inwazje oraz klęski naturalne ${ }^{1}$, natomiast obecnie znacząco zmieniły się ich uwarunkowania, powiązane choćby z takimi czynnikami jak globalizacja i ekonomia. O skali migracji mogą świadczyć dane zaczerpnięte ze źródeł International Organization for Migration, będącej agendą powiązaną ONZ, która podaje, że liczba migrantów na świecie wynosi około $250 \mathrm{mln}$ ludzi, co stanowi 3,4\% światowej populacji ${ }^{2}$.

${ }^{1}$ D. Robertson, Słownik polityki, przeł. M. Dera et al., Warszawa 2009, s. 150.

${ }^{2}$ Migracje międzynarodowe i ekspatriacja. Perspektywa indywidualna, organizacyjna, społeczno-kulturowa, red. S. Przytuła, Warszawa 2017, s. 11. 
Rozpatrywanie współczesnych strumieni migracyjnych jest zatem niezmiernie ciekawym obszarem zainteresowania naukowego wielu środowisk badawczych, w tym także związanych z naukami o bezpieczeństwie. Wpływ migracji na współczesne bezpieczeństwo jest bowiem niezaprzeczalny. Analizując zatem migracje, w perspektywie zarówno emigracji, jak i imigracji, na obszarze Polski i Unii Europejskiej, celowe jest zwrócenie uwagi na pewne cechy charakterystyczne tego zjawiska oraz wskazanie tych zagrożeń i wyzwań, które pojawiły się wraz z tym procesem, być może jeszcze nie na terenie naszego kraju, ale ich identyfikacja w zjednoczonej Europie przyczyni się do podniesienia poziomu bezpieczeństwa w wymiarze narodowym i unijnym.

\section{Przyczyny i skutki migracji}

Zdefiniowanie i skategoryzowanie wszystkich przyczyn, dla których ludzie decydują się na opuszczenie dotychczasowego miejsca pobytu i poszukiwanie innego, jest niezmiernie trudne. Jednym z podstawowych kryteriów jej podziału, patrząc z perspektywy miejsca, do którego osoba przybywa lub z którego wyjeżdża, jest dychotomiczny podział na emigrację, (łacińskie emigratio, czyli wyprowadzenie się) rozumiane jako ruch wędrówkowy (odpływ) ludności poza granice określonego terytorium; oraz imigrację, (łacińskie immigrare -wprowadzić się), oznaczające napływ ludności na dane terytorium, zwykle terytorium państwa; a potocznie przybycie do kraju w celu osiedlenia się lub długotrwałego pobytu ${ }^{3}$. Kolejnym kryterium może być perspektywa przekroczenia granicy zewnętrznej danego państwa. Mamy wtedy do czynienia $\mathrm{z}$ migracją zewnętrzną. W wypadku przemieszczania się $\mathrm{w}$ obrębie danego terytorium mówimy o migracji wewnętrznej.

Badając przyczyny współczesnych procesów migracyjnych, można podzielić je na następujące grupy ${ }^{4}$ :

- ekonomiczne i demograficzne, wśród których do czynników wypychających zaliczymy: ubóstwo, bezrobocie, niskie płace, wysoki przyrost naturalny, nieodpowiednia opieka zdrowotna oraz nieodpowiedni poziom edukacji; natomiast do przyciągających takie czynniki, jak: perspektywa lepszych zarobków i poprawy warunków życiowych oraz rozwój osobisty i zawodowy;

- polityczne, wśród których warto wymienić zagrożenia życia i zdrowia, korupcję i łamanie praw człowieka jako czynniki wypychające oraz poczucie bezpieczeństwa i wolności politycznej jako uwarunkowania sprzyjające przyjazdowi do kraju przyjmującego;

\footnotetext{
${ }^{3}$ www.encyklopedia.pwn.pl (dostęp: 29.11.2018).

${ }^{4}$ World Bank, Migration and Remittances. Easter and the Europe former Soviet Union, [w:] Migracje międzynarodowe i ekspatriacja. Perspektywa indywidualna, organizacyjna, społeczno-kulturowa, red. S. Przytuła, Warszawa 2017, s. 63.
} 
- społeczno-kulturowe, wśród których należy wyróżnić dyskryminację ze względu na przynależność etniczną lub religijną, wśród zaś czynników przyciągających łączenie rodzin, przyjazd do kraju pochodzenia przodków oraz niedyskryminowanie.

Uogólniając, można zatem przyjąć, że migracje:

- występują w każdym typie społeczeństwa;

- są zjawiskiem powszechnym, albowiem człowiek migrował od zawsze;

- dotyczą pojedynczych osób i całych grup społecznych;

- mają subiektywny charakter wynikający z przeniesienia się jednej społeczności do drugiej;

- związane są z ruchem fizycznym i zmianą miejsca zamieszkania;

- powodują zmiany w otoczeniu społecznym, kulturalnym, ekonomicznym, politycznym, środowiskowym;

- powodują różnorodne skutki;

- mają różne przyczyny.

Zarówno w pierwszej, jak i drugiej dekadzie XXI wieku jesteśmy świadkami nieustannych ruchów migracyjnych, które przetaczają się zarówno przez całą Europę, jak i Polskę. Wielkie strumienie migracyjne niosą wiele skutków o różnorodnym charakterze, które dotykają zarówno kraje przyjmujące, jak i te, z których ludność masowo odpływa. Pojawiają się zatem liczne problemy, zwłaszcza na gruncie politycznym, społecznym, ekonomicznym, demograficznym i kulturowym, z którymi muszą się zderzać społeczeństwa i rządy obu stron. Nie bez znaczenia są też sprawy związane z fundamentalną dla każdego człowieka wartością, jaką jest bezpieczeństwo, na co zwracają uwagę politolodzy:

Kwestie bezpieczeństwa tradycyjnie rozpatrywano w świetle bezpieczeństwa państwa. W rezultacie względnie niewielu badaczy podejmowało próby teoretycznego ujęcia kompleksu zjawisk, który można określić mianem splotu powiązań między migracją a bezpieczeństwem. A przecież problematyka bezpieczeństwa ma znacznie szerszy zakres i obejmuje również bezpieczeństwo ludności. Brak bezpieczeństwa stanowi częste doświadczenie międzynarodowych migrantów. W gruncie rzeczy, to właśnie ich brak bezpieczeństwa powinien stać się najważniejszym problemem w badaniach nad bezpieczeństwem ${ }^{5}$.

Można zatem postawić tezę, że współczesne migracje wpływają w znaczący sposób na niemal wszystkie dziedziny bezpieczeństwa (patrząc w ujęciu przedmiotowym), jak: bezpieczeństwo polityczne, społeczne, kulturowe, ekonomiczne czy demograficzne. W dalszej części artykułu szczegółowo przeanalizuję te obszary.

Patrząc na problem migracji z polskiej perspektywy, warto rozpocząć od przypomnienia, że wejście Polski do Unii Europejskiej w 2004 roku otwarło szeroko rynki pracy państw Europy Zachodniej, w wyniku czego z kraju systematycznie

${ }^{5}$ S. Castles, M.J. Miller, Migracje we współczesnym świecie, przeł. A. Gąsior-Niemiec, Warszawa 2011, s. 261.

Forum Socjologiczne 10, 2020

(C) for this edition by CNS 
zaczęli wyjeżdżać ludzie w poszukiwaniu nie tylko lepszej pracy, lecz także godziwych warunków życia. Można przyjąć, że w latach 2010-2015 z Polski wyjechało od 2 do 2,39 mln osób, z czego największa grupa do Wielkiej Brytanii - 720 tys. oraz do Niemiec -655 tys. ${ }^{6}$. Warto również dodać, że wśród tej grupy ponad $50 \%$ osób przebywających na wyspach oraz prawie $40 \%$ będących w Niemczech deklarowało chęć pozostania na stałe w tych krajach ${ }^{7}$.

Pełną skalę polskiej emigracji ukazują dane ze spisów powszechnych, z których wynika że w latach 2002-2011 liczba Polaków przebywających za granicą wzrosła $\mathrm{z}$ około 780 tys. do ponad $2 \mathrm{mln}^{8}$. Cechą charakterystyczną tego okresu jest zjawisko zwiększonej mobilności nie tylko Polaków, lecz w ogóle Europejczyków, którzy z różnych przyczyn przemieszczali się do innych państw Unii Europejskiej oraz poza jej granice.

Wśród czynników przyciągających Polaków na zagraniczne rynki pracy najistotniejszy bez wątpienia jest czynnik ekonomiczny. Dane GUS-u wskazują, że w grudniu 2017 roku średnia płaca w Polsce wynosiła 4973 zł brutto, co w przeliczeniu na walutę Unii Europejskiej dawało 1189 euro. Natomiast w krajach będących popularnymi celami polskiej emigracji średnia pensja wynosiła dużo więcej. Najwyższa była w Niemczech - 3730 euro, następnie we Francji 2957 euro, we Włoszech - 2560 euro, w Wielkiej Brytanii - 2482 euro oraz w Hiszpanii - 2189 euro $^{9}$. Oczywiście należy od tego odliczyć znacznie wyższe koszty wynajmu lub zakupu mieszkania oraz utrzymania, jednak i tak bilans wychodzi zdecydowanie na korzyść zarobków w innych państwach.

Tak duża liczba emigrantów nie mogła nie spowodować różnorodnych skutków - zarówno pozytywnych, jak i negatywnych - występujących w kraju macierzystym oraz w kraju przyjmującym. Podsumowując korzyści płynące z emigracji Polaków do innych krajów, można je ująć następująco:

- zdobycie doświadczenia, nauka języka, uzyskanie kapitału na otwarcie własnych przedsiębiorstw;

- poprawa sytuacji materialnej, zarówno tych, którzy pozostali w kraju, jak i tych, którzy zdecydowali się pracować zagranicą;

— zwiększenie liczby pracowników w krajach europejskich, którzy mogą realizować prace za niższe wynagrodzenie, co jest zaletą z perspektywy krajów przyjmujących imigrantów;

— zwiększenie dzietności Polek za granicą, co też jest korzystne dla krajów przyjmujących;

- czasowe zmniejszenie poziomu bezrobocia, zwłaszcza w regionach, gdzie jego poziom utrzymywał się przez dłuższy czas na znacznym poziomie.

\footnotetext{
${ }^{6}$ Dane z 5 września 2016 roku, www.gus.gov.pl (dostęp: 16.04.2018).

${ }^{7}$ Ibidem.

${ }^{8}$ Powroty z emigracji, 15.04.2018, www.wPolityce.pl (dostęp: 22.02.2019).

${ }^{9}$ www.wynagrodzenia.pl (dostęp: 25.03.2018).
} 
Niestety masowa emigracja przyniosła również skutki negatywne, do których można zaliczyć:

— problemy i konflikty kulturowe pojawiające się w środowiskach imigrantów;

- rozwój niechęci rodowitych mieszkańców krajów Europy Zachodniej wobec przyjezdnych, w tym Polaków;

- wyjazd pracowników i specjalistów w wieku produkcyjnym, którzy mogliby budować polską gospodarkę (drenaż mózgów);

- problemy rodzinne, związane $\mathrm{z}$ zaburzeniem funkcjonowania rodziny, wzrostem liczby rozwodów spowodowanych długotrwałą rozłąką czy zjawiskiem eurosieroctwa;

— podatność imigrantów na różnego rodzaju patologie (przestępczość, alkoholizm, prostytucja), depresje i problemy z adaptacją w nowym, nie zawsze przyjaznym środowisku;

- podejmowanie pracy niezgodnej z wykształceniem i aspiracjami, gorzej płatnej, często z pogwałceniem kodeksu pracy czy zasad bezpieczeństwa i higieny pracy;

- braki kadrowe, zwłaszcza wśród specjalistów określonych zawodów na macierzystym rynku pracy, a tym samym konieczność uzupełniania tych braków ludźmi z innych państw.

Jak eksperci oceniają szanse na powrót Polaków z emigracji? Opinie na ten temat są podzielone. Jedni argumentują, że sytuacja w Polsce od czasu wejścia do Unii Europejskiej diametralnie się zmieniła niemal w każdym aspekcie życia społecznego, ekonomicznego i kulturowego. Mamy rekordowo niskie bezrobocie, albowiem stopa bezrobocia w lutym 2018 roku wyniosła 6,8\% (spadła o 0,1 pkt proc. w stosunku do stycznia i o 1,6 pkt proc. w porównaniu z lutym 2017 roku), poprawiła się koniunktura gospodarcza, a Narodowy Bank Polski w Raporcie o inflacji pisze o bardzo dobrych nastrojach konsumentów ${ }^{10}$. Zachętą do powrotu mają być różnego rodzaju programy skierowane do reemigrantów, jak na przykład przygotowany przez Ministerstwo Rodziny, Pracy i Polityki Społecznej projekt ustawy o rynku pracy, który zakłada, że powracający do kraju emigranci będą mogli pożyczyć z Funduszu Pracy nawet dwudziestokrotność średniej pensji. To oznacza ponad 85 tys. zł, w dodatku symbolicznie oprocentowane $(0,43 \%$ w skali roku). Niestety projekt miał być przyjęty przez Radę Ministrów w trzecim kwartale 2018 roku, jednakże ze względu na liczne uwagi zgłaszane przez podmioty konsultujące ten dokument został on ponownie skierowany do ministerstwa w celu naniesienia poprawek ${ }^{11}$.

Mimo to z badań przeprowadzonych przez Work Service i NBP wynika, że większość Polaków, którzy wyemigrowali po 2005 roku, zdążyło się w miejscach

10 Powroty $z$ emigracji...

11 J. Ceglarz, 15 lat na emigracji. Dziś mówią: „wracamy!”, 20.10.2018, www.money.pl (dostęp: 21.01.2019). 
wyjazdu zakorzenić: mają dobrą pracę, rodziny, przyjaciół, ładne mieszkania, ich dzieci chodzą do dobrych szkół. W Wielkiej Brytanii 54\% emigrantów nawet nie rozważa powrotu do Polski, a w rok potroiła się liczba naszych rodaków składających wnioski o brytyjskie obywatelstwo ${ }^{12}$. Jeżeli ktoś decyduje się na powrót, to najczęściej są to osoby po czterech dekadach emigracji w USA, aby spokojnie żyć za amerykańską emeryturę na ojcowiźnie.

Nie bez znaczenia pozostaje sprawa fundamentalna, czyli bezpieczeństwa w kontekście zarówno Polski, jak i innych krajów europejskich. Z polskiej perspektywy można mówić o znaczącej jego poprawie, zwłaszcza w obszarze drobnej przestępczości oraz bezpieczeństwa w miejscach publicznych, a także prawdopodobieństwa wystąpienia zamachów terrorystycznych, które jest o wiele mniejsze niż w innych krajach europejskich.

Przechodząc do analizy sytuacji właśnie na terenie Unii Europejskiej, warto rozpocząć od konstatacji, że napływ ogromnych mas ludzi, zapoczątkowany arabską wiosną w 2011 roku, zachwiał gwałtownie stabilnym życiem mieszkańców zjednoczonej Europy. Ponad 2 mln osób obcego pochodzenia, które w gwałtowny i najczęściej nielegalny sposób wdarły się na kontynent europejski, zaburzyły funkcjonowanie państw w wymiarze politycznym, ekonomicznym, kulturowym i społecznym.

Politolodzy zauważają, że

przed 11 września 2001 r. badacze zajmujący się stosunkami międzynarodowymi i bezpieczeństwem międzynarodowym poświęcali bardzo mało uwagi międzynarodowej migracji. I na odwrót - badacze zajmujący się międzynarodową migracją rzadko analizowali jej implikacje dla bezpieczeństwa czy zrozumienia stosunków międzynarodowych bądź polityki światowej ${ }^{13}$.

Obecnie sytuacja ta diametralnie się zmieniła. Migranci stali się prawdziwym wyzwaniem dla państw unijnych, które jeszcze nie tak dawno, bo w połowie ubiegłego wieku, traktowały ich jako ratunek w wielu sektorach gospodarki czy też w kwestii polepszenia sytuacji demograficznej kraju. Jednakże niekontrolowana migracja $\mathrm{w}$ krótkim czasie stała się jednym $\mathrm{z}$ największych problemów, z jakim mierzą się kraje europejskie, zwłaszcza skupione wokół basenu Morza Śródziemnego.

Zmiany, jakie zaszły na terenie Bliskiego Wschodu oraz Afryki Północnej, zdaniem ekspertów stały się bezpośrednio lub pośrednio przyczyną wielkiego kryzysu migracyjnego, przed jakim stanęły kraje Europy Zachodniej, zwłaszcza położone w południowo-zachodniej części kontynentu europejskiego. Za początek tych zmian przyjmuje się grudzień 2010 roku, a ich źródłem w opinii obserwatorów, jest rewolucja w Tunezji i Egipcie oraz seria antyrządowych wystąpień, które

12 Z. Bartuś, Polacy (na razie) nie wracaja z emigracji. Zarobki i „ta kultura”, 12.06.2017, www. dziennikpolski24.pl (dostęp: 21.02.2019).

13 S. Castles, M.J. Miller, op. cit., s. 256.

Forum Socjologiczne 10, 2020

(C) for this edition by CNS 
ogarnęly kraje regionu ${ }^{14}$. Na powstanie oraz ekspansję niezadowolenia i protestów społecznych wpływ miało co najmniej kilka czynników, wśród których na uwagę zasługują kwestie ekonomiczne, społeczno-polityczne oraz demograficzne i religijne. Wydarzenia te dla państw europejskich były brzemienne w skutkach, ponieważ fala niezadowolonych z warunków życia ludzi ruszyła w kierunku Europy, czego skutkiem było złożenie w 2015 roku ponad 1,2 mln wniosków o azyl ${ }^{15}$. Jak duża jest skala zjawiska? Na podstawie danych International Organization for Migration można podać, że do Europy w 2016 roku przybyło ponad 390 tys. nielegalnych imigrantów, w 2017 roku było ich ponad 180 tys. a do listopada 2018 roku odnotowano przyjazd prawie 130 tys., z czego ponad 106 tys. drogą morską, a reszta lądem ${ }^{16}$.

Specyfika obecnego kryzysu migracyjnego wynikająca z aspektu demograficznego, widocznego szczególnie w dużej dysproporcji młodych mężczyzn w stosunku do kobiet oraz trudności w integracji imigrantów ze społeczeństwem przyjmującym, zwłaszcza w obszarze społecznym i kulturowym ${ }^{17}$, wskazuje, że wśród podstawowych czynników wypychająco-przyciągających można wymienić przede wszystkim aspekty finansowe, wynikające $\mathrm{z}$ wysokich stawek zasiłków socjalnych przyznawanych imigrantom oraz pozostałe aspekty opieki społecznej udzielanej ich wielodzietnym rodzinom. Dla przykładu - w Niemczech w 2015 roku imigrant oprócz zakwaterowania, wyżywienia i ubrań otrzymywał pieniądze na własne wydatki w kwocie 352 euro miesięcznie, z czego 143 euro w gotówce. W przypadku rodziny suma wszystkich świadczeń mogła wynosić nawet do 1000 euro miesięcznie ${ }^{18}$. Jako ciekawostkę można przytoczyć sprawę jednego Syryjczyka, który w 2015 roku otrzymał z niemieckiego budżetu aż 360 tys. euro zapomogi, ponieważ miał na utrzymaniu cztery żony (islam daje mężczyźnie prawo do posiadania czterech żon, o ile jest w stanie utrzymać liczną rodzinę) oraz dwadzieścioro troje dzieci ${ }^{19}$.

Jednakże świadczenia materialne nie są jedynym powodem popularności krajów Europy Zachodniej wśród imigrantów, którzy wybierając kierunek migracji, rozważają takie czynniki, jak: praworządność, nieistnienie korupcji, dobre perspektywy zawodowe, możliwość edukacji dla dzieci oraz poczucie bezpieczeństwa, a także, co jest bardzo istotne - obecność w danym kraju osób tego samego

14 A. Dzisiów-Szuszczykiewicz, „Arabska wiosna” - przyczyny, przebieg i prognozy, „Bezpieczeństwo Narodowe" 2011, nr 2, s. 42, www.bbn.gov.pl (dostęp: 29.11.2018).

15 www.polskieradio.pl (dostęp: 17.05.2018).

${ }^{16}$ www.poland.iom.int (dostęp: 29.11.2018).

17 J.L. Bazan, A retugee crisis in Europe? Questioning perception in the current migration debate, [w:] Kryzys migracyjny w Europie. Wyzwania etyczne, społeczno-kulturowe i etniczne, red. J. Balicki, W. Necel, Warszawa 2017, s. 38.

18 „Raj nazywa się Almaniya”. Co przyciaga imigrantów do Niemiec, 16.09.2015, www.tvn24.pl/ (dostęp: 3.12.2018).

19 Ponad 6 mln imigrantów i uchodźców czeka u wrót Europy. Kim są i skąd pochodzą, 12.06.2107, www.tvp.info (dostęp: 3.12.2018). 
pochodzenia, którzy wyemigrowali już wcześniej i stanowią punkt zaczepienia w pierwszych miesiącach pobytu na obczyźnie. Warto również zwrócić uwagę, iż wśród imigrantów ogromna rzesza ubiega się o status azylanta lub uchodźcy ${ }^{20}$, motywując swój przyjazd do kraju przyjmującego czynnikami politycznymi, takimi jak prześladowania, obawa o życie i zdrowie czy działaniami wojennymi. Nie bez znaczenia dla fali migrantów jest też wielka popularność, jaką cieszą się wśród imigrantów zwłaszcza Niemcy, a także Wielka Brytania i Francja, szerzona przez media społecznościowe, telewizję lub po prostu pocztą pantoflową. Programy te, przedstawiając kraje europejskie jako bardzo przyjazne dla imigrantów, są odbierane w obozach dla uchodźców, dodatkowo motywują do przedostania się do nich za wszelką cenę ${ }^{21}$. Stąd też setki ofiar na Morzu Śródziemnym, usiłujących przepłynąć ten akwen często w niehumanitarnych warunkach zagrażających życiu i zdrowiu. Międzynarodowa Organizacja do spraw Migracji nazywa to morze „najbardziej zabójczą granicą świata”, ponieważ od 2000 roku w śródziemnomorskich wodach utonęło ponad 33 tys. ludzi ${ }^{22}$.

Strumienie migracyjne nie ominęły również Polski, na której terenie mamy już do czynienia ze znacznym wzrostem liczby cudzoziemców, których systematycznie przybywa. Od 2014 roku stale odnotowujemy przyrost liczba obcokrajowców ubiegających się o zezwolenia na pobyt w Polsce. Przeważają migracje czasowe w 2017 roku 88\% wniosków dotyczyło zezwoleń na pobyt czasowy (do trzech lat), $10 \%$ pobytu stałego, a $2 \%$ pobytu rezydenta długoterminowego UE. Prawie $65 \%$ wszystkich wniosków złożyły osoby w przedziale wiekowym 20-39 lat ${ }^{23}$. Najczęściej w Polsce chcieli zamieszkać obywatele Ukrainy, którzy złożyli w 2017 roku 125 tys. wniosków - o 30\% więcej niż w 2016 roku. O zezwolenia na pobyt ubiegali się także: Białorusini (9,5 tys.), Hindusi (8 tys.), Wietnamczycy (6,4 tys.) oraz Chińczycy (6 tys.). Jeszcze w 2005 roku prawo stałego pobytu w Polsce miało 858 osób, a w 2014 już 18,9 tys., z czego najwięcej Chińczyków, Wietnamczyków, Ukraińców ${ }^{24}$. Dla wielu imigrantów, zwłaszcza przybywających z Bliskiego Wschodu, nasz kraj jest najczęściej traktowany jako tranzytowy w drodze do zamożniejszych krajów zachodnioeuropejskich, to z powodu zewnętrznej granicy Unii Europejskiej pojawia się wiele problemów wymagających szczególnych działań od służb odpowiedzialnych za poszczególne dziedziny bezpieczeństwa narodowego.

${ }^{20}$ Azylant to uchodźca, któremu jakieś państwo udzieliło azylu. Uchodźstwo oznacza stały lub czasowy pobyt poza granicami własnego państwa, spowodowany przyczynami ekonomicznymi, politycznymi lub religijnymi. Zob. Słownik Języka Polskiego PWN, www.sjp.pwn.pl (dostęp: 3.12.2018).

21 „Raj nazywa się Almaniya”...

22 Ponad 33 tys. osób utonęło w Morzu Śródziemnym w drodze do Europy, 11.12.2017, www. euroactiv.pl (dostęp: 3.12.2018).

${ }^{23}$ Rośnie w Polsce liczba cudzoziemców, 2.02.2018, www.ekai.pl (dostęp: 3.04.2018).

${ }^{24}$ Urząd do spraw Cudzoziemców, www.udsc.gov.pl (dostęp: 7.05.2018).

Forum Socjologiczne 10, 2020

(C) for this edition by CNS 


\section{Wpływ migracji na wybrane obszary bezpieczeństwa narodowego}

Dokonując analizy poszczególnych dziedzin bezpieczeństwa, warto wskazać te zagrożenia i wyzwania, które mogą lub już pojawiły się w życiu społeczeństw europejskich i wynikają właśnie z migracji. Przyjęcie dużej liczby imigrantów implikuje poważne wyzwania dla bezpieczeństwa społeczeństw i to praktycznie we wszystkich obszarach ich funkcjonowania. W obszarze bezpieczeństwa społecznego imigranci są dużym obciążeniem dla budżetu państwa, w wymiarze zarówno lokalnym, jak i regionalnym, który to musi ponosić ciężar świadczeń socjalnych - materialnych i finansowych dla nowo przybyłych osób oraz systemu zabezpieczeń społecznych. To również problem pojawiających się patologii społecznych, na czele $\mathrm{z}$ alkoholizmem, narkomanią czy prostytucją, które są charakterystyczne dla społeczeństwa zarówno przyjmującego, jak i przybywającego. Osobną kwestią jest model rodziny, z jakim mamy do czynienia w społecznościach muzułmańskich. Najczęściej są to rodziny wielodzietne, patriarchalne, z uprzywilejowaną pozycją mężczyzny oraz znacznie słabszą rolą kobiety, która często z powodu braku wykształcenia oraz znajomości języka ma utrudniony kontakt $\mathrm{z}$ otoczeniem zewnętrznym, a w skrajnych przypadkach może stać się ofiarą przemocy domowej. Do tego należy dodać kwestię dzieci, z którymi wiążą się kolejne problemy. Według danych niemieckiego Ministerstwa Spraw Wewnętrznych w 2015 roku na terenie tego kraju zaginęło prawie 6 tys. nieletnich, głównie z Afganistanu, Erytrei i Syrii. Najprawdopodobniej trafiły w ręce handlarzy ludźmi, a następnie do organizacji przestępczych, które wykorzystują ich do niewolniczej pracy lub usług seksualnych ${ }^{25}$. Kolejnym wyzwaniem jest zapewnienie dostępu do edukacji, która jest znaczącym instrumentem integracji środowisk migracyjnych ze społeczeństwem goszczącym. Jednak jak wskazują międzynarodowe badania, obserwuje się zjawisko rezygnacji ze szkoły wśród uczniów pochodzących z rodzin imigrantów ${ }^{26}$. Tym samym zamiast niwelować różnice w poziomie wykształcenia, stale się je pogłębia, a to oznacza w dalszej perspektywie wykonywanie gorszej pracy, trudności komunikacyjne i kulturowe.

$\mathrm{Z}$ bezpieczeństwem społecznym wiąże się również kwestia dostępności rynku pracy. Zgodnie z polityką Rady Europy w tym zakresie kraje unijne powinny dążyć do osiągnięcia wskaźnika zatrudnienia na poziomie $75 \%$ wśród kobiet i mężczyzn w wieku produkcyjnym, zwiększenia aktywności zawodowej młodzieży, osób starszych, nisko wykwalifikowanych oraz skuteczniejszej integracji legalnych migrantów ${ }^{27}$. A co z imigrantami nielegalnymi? Z jednej strony stano-

${ }^{25}$ Niemcy nie mogq odnaleźć sześciu tysięcy dzieci-imigrantów, 11.04.2016, www.tvn24.pl (dostęp: 4.12.2018).

26 A. Cudowska, Polityka oświatowa Unii Europejskiej wobec migracji, „Pogranicze. Studia Społeczne" 30, 2017, www.cejsh.icm.pl (dostęp: 4.12.2018).

${ }_{27}$ Rada Europy, Nowa europejska strategia na rzecz zatrudniania i wzrostu gospodarczego. Wymierne cele UE. Konkluzje, 17.06.2010, [w:] J. Balicki, Imigranci i uchodźcy w Unii Europejskiej, humanizacja polityki imigracyjnej i azylowej, Warszawa 2012, s. 30.

Forum Socjologiczne 10, 2020

(C) for this edition by CNS 
wią oni doskonałe źródło taniej siły roboczej, zwłaszcza w tych sektorach, w których nie jest wymagane wyższe czy specjalistyczne wykształcenie. Z drugiej zaś napływ większej liczby osób, niż może przyjąć lokalny rynek pracy, powoduje dodatkowe trudności w jej pozyskaniu, proponowanie stawek niezgodnych z polityką płacową państwa czy wręcz wyzysk w postaci nielegalnego zatrudniania (na czarno), bez odprowadzania stosownych składek emerytalnych i zdrowotnych. Wszystkie te czynniki mogą wpływać niekorzystnie na bezpieczeństwo ekonomiczne regionu, pogłębiając już i tak słabą kondycję gospodarczą niektórych z nich. Utrzymująca się długotrwale taka sytuacja może doprowadzić do frustracji, korupcji, wzrostu przestępczości pospolitej czy wybryków chuligańskich oraz jawnego niezadowolenia obu stron narastającego konfliktu społecznego ${ }^{28}$.

Może to z kolei prowadzić do zachwiania bezpieczeństwa i porządku publicznego, czego przykładów możemy doszukiwać się w wielu miastach europejskich. Rażącym tego przejawem są akty terroru dokonane w ostatnich kilku latach w wielu miastach europejskich czy też molestowanie kobiet w noc sylwestrową w Kolonii w 2015 roku. Warto również zwrócić uwagę na wzmożoną działalność mafijnych grup przestępczych czy wzrost przestępczości pospolitej i kryminalnej, co wobec bezradności policji, która często boryka się z problemami kadrowymi, rodzi bardzo poważne konsekwencje w kwestii bezpieczeństwa mieszkańców regionu. Przykładem w tym zakresie mogą być Niemcy, gdzie w 2014 roku odnotowano 181 tys. aktów przemocy, a dwa lata później ich poziom wzrósł do 193,5 tys. Jeżeli chodzi o wskaźniki dla jednego z niemieckich landów - Dolnej Saksonii - wzrost przestępczości był jeszcze bardziej widoczny. Z poziomu 17,5 tysiąca przestępstw w 2014 roku w kolejnych dwóch latach ich liczba wzrosła do 19,2 tys. I co istotne, za $92 \% \mathrm{z}$ nich odpowiadają osoby obcego pochodzenia $^{29}$. W rzeczywistości liczba popełnianych przestępstw nie jest do końca precyzyjna, ponieważ nie wszystkie są zgłaszane policji, zwłaszcza w tych dzielnicach, do których funkcjonariusze nie mają możliwości wjazdu z obawy o swoje bezpieczeństwo. $Z$ zapewnieniem bezpieczeństwa i porządku publicznego wiąże się również kwestia tak zwanego no go zone lub no go area, charakterystycznego dla obrzeży szwedzkich miast, takich jak Sztokholm, Malmö i Göteborga. Samo określenie oznacza takie obszary, w których poziom przemocy i przestępczości jest tak wysoki, że uniemożliwia ludziom normalne funkcjonowanie i zmusza ich do życia w ciągłym strachu ${ }^{30}$. Spacer po niektórych częściach miasta może zagrażać życiu i zdrowiu nie tylko obywateli, lecz także służb mundurowych, w tym policji.

Jeszcze większe trudności pojawiają się w zakresie bezpieczeństwa kulturowego, w którego obszarze może pojawić się wiele zagrożeń wynikających

${ }^{28}$ M. Ślęzak, Współczesne migracje i uchodźctwo a bezpieczeństwo społeczne, [w:] Kryzys migracyjny w Europie..., s. 54.

${ }^{29}$ Przestępczość imigrantów w Niemczech: fakty i mity, 23.01.2018, www.polityka.pl (dostęp: 1.12.2018).

${ }^{30}$ https://joemonster.org/art/42124 (dostęp: 23.08.2019). 
z odmiennej kultury ludności napływowej i trudności w adaptacji w nowym środowisku. Dokonując przeglądu teorii w tym zakresie, można wyodrębnić trzy zasadnicze okresy. Pierwszy, przypadający na lata pięćdziesiąte-sześćdziesiąte $\mathrm{XX}$ wieku, zakładał stopniowe „stapianie się" kulturowe, religijne i cywilizacyjne imigrantów w społeczeństwie przyjmującym. Kolejny okres przypada na lata osiemdziesiąte-dziewięćdziesiąte ubiegłego wieku, kiedy to obowiązywała zasada wielokulturowości oznaczająca, że imigranci i społeczeństwo przyjmujące trwają obok siebie, równocześnie akceptując swą odmienność, zgodnie z zasadą wielobarwności, zróżnicowania i pluralizmu kulturowego. Współcześnie można mówić o niechęci kulturowej, odznaczającej się nieakceptacją przez obie strony odrębności kulturowej, religijnej i cywilizacyjnej. Odmienność ta budzi również obawy o zachowanie tożsamości kulturowej wśród rdzennej ludności, której potrzeby w tym zakresie mogą być spychane przez dominującą kulturę imigrantów. Przykładem takiej sytuacji może być referendum przeprowadzone w 2009 roku w Szwajcarii na temat budowy minaretów przy meczetach, w którym Szwajcarzy nie wyrazili na to zgody.

Nie bez znaczenia jest również bezpieczeństwo zdrowotne, które zaniedbane może przysporzyć społecznościom europejskim znacznych kłopotów, a nawet strat w ludziach. Europejskie Centrum Profilaktyki i Kontroli Zakażeń zaleca, aby stan zdrowia migrantów był sprawdzany już przy wjeździe do Unii Europejskiej, a w czasie ich pobytu powinny zostać zapewnione podstawowe warunki do życia: mieszkanie, sanitariaty, dostęp do bieżącej wody oraz właściwe wyżywienie. Ponadto niezbędne jest prowadzenie odpowiedniej edukacji prozdrowotnej oraz szczepień profilaktycznych ${ }^{31}$. Za szczególnie niebezpieczne wskazuje się te choroby zakaźne, które mogą w krótkim czasie rozprzestrzeniać się na dużym terytorium, powodując masowe zachorowania ludzi, takie jak na przykład gruźlica, malaria czy HIV.

Postawa społeczeństw europejskich obserwowana w ciągu kilkuletniego kryzysu migracyjnego również się zmianiła. Mimo wcześniejszych chęci niesienia pomocy obywatele Unii Europejskiej są raczej negatywnie nastawieni do przyjmowania uchodźców. Taka postawa wynika przede wszystkim z obawy o własne bezpieczeństwo.

Wśród rdzennych mieszkańców Europy imigranci wywołują różne odczucia, co pokazują między innymi badania przeprowadzone przez organizację YouGov wśród mieszkańców siedmiu europejskich krajów, których zapytano, co czują na myśl o napływających do Europy imigrantach. Ich zadaniem było opisanie tych uczuć za pomocą wyłącznie jednego słowa. Okazało się, że większość mieszkańców czuje w stosunku do uchodźców strach, złość, bezradność czy smutek.

${ }^{31}$ Cała prawda o zdrowiu uchodźców, 5.11.2015, www.medexpess.pl (dostęp: 3.12.2018). 
Zdecydowanie mniej było osób, które na myśl o uchodźcach odczuwały na przykład współczucie ${ }^{32}$.

Niestety sami imigranci często pracują na tę opinię, ponieważ wielokrotnie nagłaśniane przypadki łamania reguł i zasad zachowania się w państwie przyjmującym nie tworzy dobrego klimatu politycznego i społecznego wokół nich. I choć wielu z nich doświadcza osobistych tragedii, opinia publiczna wielu społeczeństw nie jest przychylnie nastawiona do przyjmowania uchodźców.

\section{Podsumowanie}

Zarysowana w dużym skrócie sytuacja współczesnych migracji tworzy poważne implikacje dla bezpieczeństwa narodowego poszczególnych państw, zwłaszcza w jego lokalnym i regionalnym wymiarze. I choć w instytucjach unijnych toczą się długotrwałe dyskusje na temat zasad relokacji imigrantów, to nie ma konsensusu w tym zakresie, a społeczności lokalne zostały postawione przed faktem pobytu $\mathrm{w}$ ich przestrzeni publicznej ludzi, którzy nie mając praktycznie nic, wierzą, że przybyli do miejsc, gdzie znajdą warunki do życia i rozwoju oraz poczucie bezpieczeństwa. Sprostanie tym potrzebom jest sporym wyzwaniem zarówno dla strony przyjmującej, jak i ludzi decydujących się na emigrację. Sytuacja polskich obywateli jest tu specyficzna. Z jednej strony jesteśmy skazani na emigrację od wieków - przez czynniki wojenne, ekonomiczne czy polityczne. Nasze doświadczenia w tym zakresie są zarówno pozytywne, jak i negatywne. $\mathrm{Z}$ drugiej zaś nasz kraj stał się atrakcyjny dla obywateli innych państw nękanych kryzysami politycznymi, ekonomicznymi czy religijnymi tak bardzo, że decydują się osiedlić w nim, jeżeli nie na stałe, to przynajmniej na dłuższy pobyt. Zatrzymanie tego procesu zarówno w Polsce, jaki i w Europie nie jest już możliwe. Możliwe jest natomiast, a wręcz niezbędne, wypracowanie takich mechanizmów, które pozwolą złagodzić trudy procesów migracyjnych, zwłaszcza w aspekcie asymilacji, i we właściwy sposób wyzyskać potencjał ludzki, który od wieków decydował a potędze państw.

\section{Bibliografia}

www.archiwum.radiozet.pl.

Balicki J., Imigranci i uchodźcy w Unii Europejskiej, humanizacja polityki imigracyjnej i azylowej,

Warszawa 2012.

www.bbn.gov.pl.

Castles S., Miller M.J., Migracje we współczesnym świecie, przeł. A. Gąsior-Niemiec, Warszawa 2011. www.cejsh.icm.pl.

${ }^{32}$ Co Europejczycy myślą o uchodźcach? Odpowiadaja jednym słowem, 1.10.2015, www.archiwum. radiozet.pl (dostęp: 12.05.2018).

Forum Socjologiczne 10, 2020

(C) for this edition by CNS 
www.dziennikpolski24.pl.

www.ekai.pl.

www.encyklopedia.pwn.pl.

www.euroactiv.pl.

www.gus.gov.pl.

Kryzys migracyjny w Europie. Wyzwania etyczne, społeczno-kulturowe i etniczne, red. J. Balicki, W. Necel,

UKSW, Warszawa 2017.

www.money.pl.

www.medexpess.pl.

Migracje międzynarodowe i ekspatriacja. Perspektywa indywidualna, organizacyjna, społeczno-

kulturowa, red. S. Przytuła, Difin, Warszawa 2017.

www.poland.iom.int.

www.polityka.pl.

www.polskieradio.pl.

Robertson D., Stownik polityki, przeł. M. Dera et al., Wyd. Sic!, Warszawa 2009.

www.sjp.pwn.pl.

www.tvn24.pl.

www.tvp.info.

www.udsc.gov.pl.

www.wPolityce.pl.

www.wynagrodzenia.pl.

\section{Migration of the 21st century as a challenge for Polish security and the European Union}

\section{Summary}

The article contains considerations about migration and its impact on the security of Poland and other European Union member states. The author indicates both positive and negative effects of emigration from Poland and immigration resulting from the Arab Spring of peoples to European countries and the impact on particular areas of security.

Keywords: security, migration, causes and effects 